
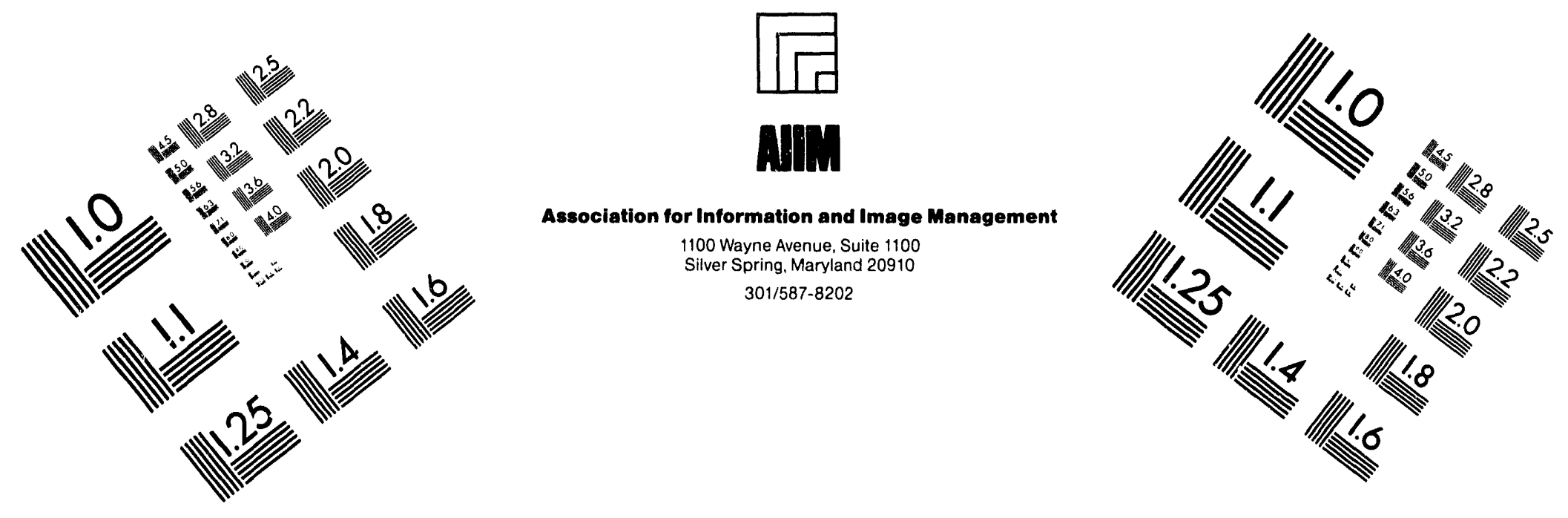

\title{
Centimeter
}

$\begin{array}{llllllllllllllll}1 & 2 & 3 & 4 & 5 & 6 & 7 & 8 & 9 & 10 & 11 & 12 & 13 & 14 & 15 & \mathrm{~mm}\end{array}$

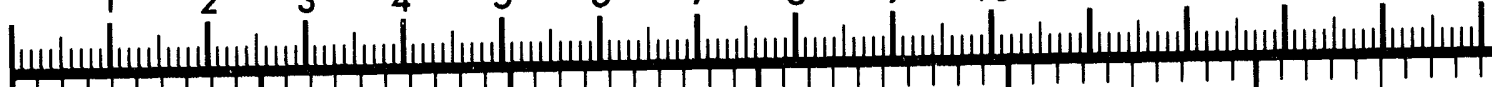

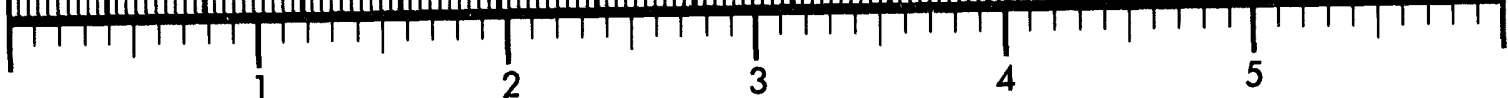
Inches

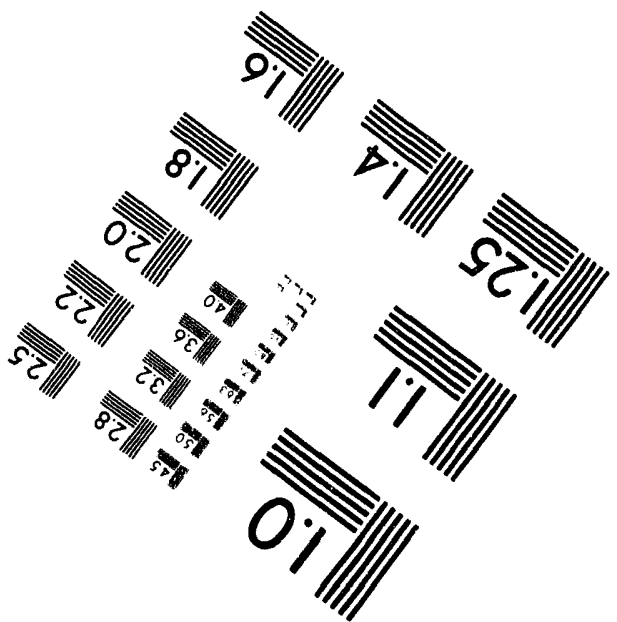

MANUFACTURED TO AIIM STANDARDS

BY APPLIED IMAGE, INC.

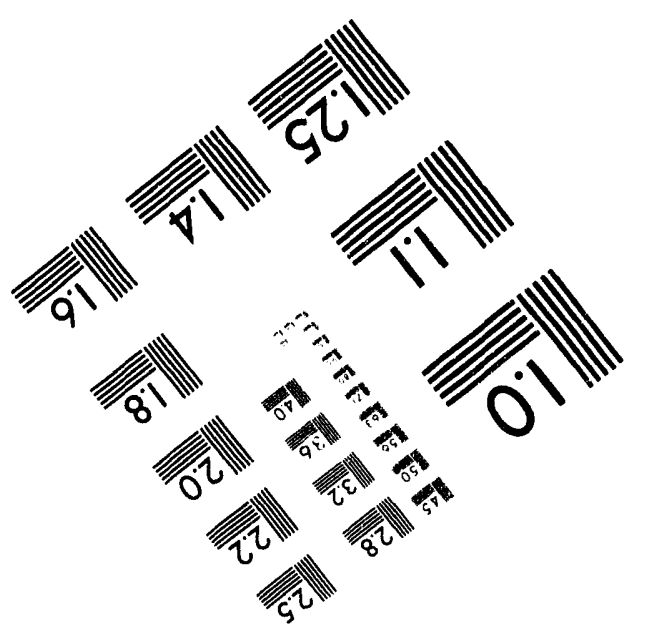



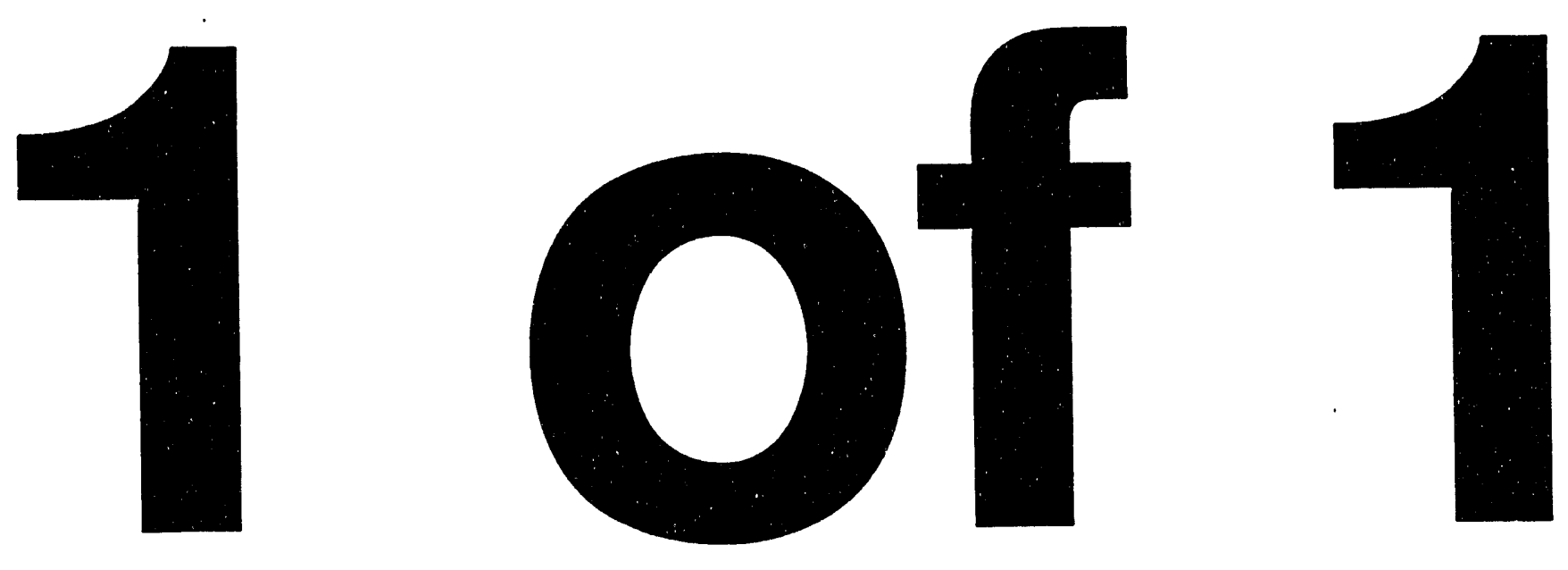


\section{Configuration Management Plan for the Automated Transportation Management System}

Prepared for the U.S. Department of Energy Office of Environmental Restoration and Waste Management

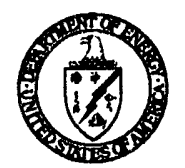

United States

Department of Energy

TTP Number RL439002

Date April 1994

Richland, Washington

Revision No: 0

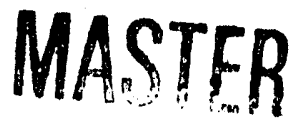

Approved for Public Release 


\section{LEGAL DISCLAIMER}

This report was prepared as an account of work sponsored by an agency of the United States Government. Neither the United States Government nor any agency thereol, nor any of their employees, nor any of their contractors, subcontractors or their employees, makes any warranty, express or implied, or assumes any legal liability or responsibility for the accuracy, completeness, or any third party's use or the results of such use of any information, apparatus, product, or process disclosed, or represents that its use would not infringe privately owned rights. Relerence herein to any specific commercial product, process, or service by trade name, trademark, manufacturer, or otherwise, does not necessarily constitute or imply its endorsement, recommendation, or lavoring by the United States Government or any agency thereof or its contractors or subcontractors. The views and opinions of authors expressed herein do not necessarily state or reflect those of the United States Government or any agency thereof.

This report has been reproduced from the best available copy. Available in paper copy and microfiche.

Available to the U.S. Department of Energy and its contractors from

Office of Scientific and Technical Information

P.0. Box 62

Oak Ridge, TN 37831

(615) $576-8401$

Available to the public from the U.S. Department of Commerce National Technical Information Service

5285 Port Royal Road

Springfield VA 22161

(703) $487-4650$

Printed in the Uniled Stales of America

DISCLM-1.CHP $(1.91)$ 
TABLE OF CONTENTS

Page

Number

1.0 INTRODUCTION $\ldots \ldots \ldots \ldots \ldots \ldots \ldots \ldots \ldots \ldots \ldots \ldots \ldots \ldots \ldots \ldots \ldots$

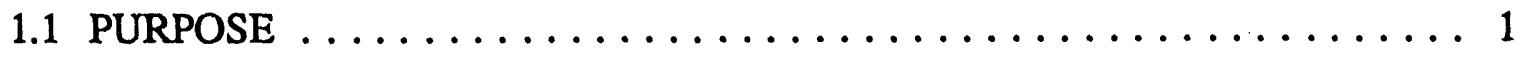

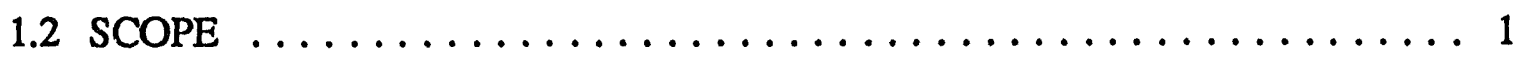

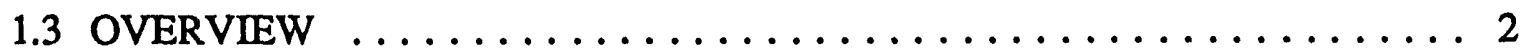

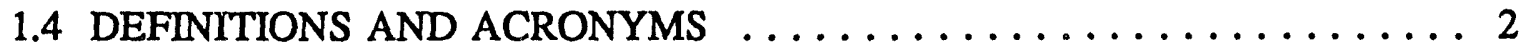

1.5 REFERENCES $\ldots \ldots \ldots \ldots \ldots \ldots \ldots \ldots \ldots \ldots \ldots \ldots \ldots$

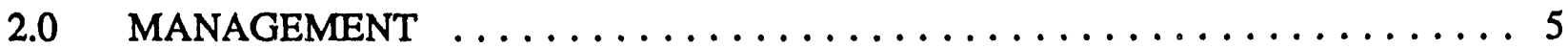

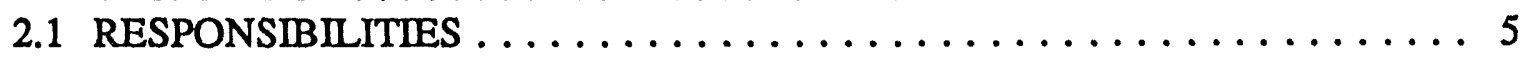

2.2 INTERFACE CONTROL $\ldots \ldots \ldots \ldots \ldots \ldots \ldots \ldots \ldots \ldots \ldots$

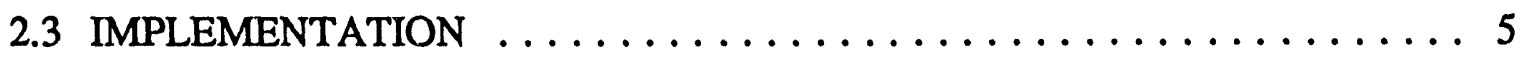

2.4 POLICIES AND PROCEDURES $\ldots \ldots \ldots \ldots \ldots \ldots \ldots \ldots \ldots \ldots$

3.0 SOFTWARE CONFIGURATION MANAGEMENT ACTIVITIES $\ldots \ldots \ldots \ldots 7$

3.1 CONFIGURATION IDENTIFICATION $\ldots \ldots \ldots \ldots \ldots \ldots \ldots \ldots \ldots$

3.2 CONFIGURATION CONTROL $\ldots \ldots \ldots \ldots \ldots \ldots \ldots \ldots \ldots \ldots$

3.3 CONFIGURATION STATUS ACCOUNTING $\ldots \ldots \ldots \ldots \ldots \ldots \ldots 8$

3.4 AUDITS AND REVIEWS $\ldots \ldots \ldots \ldots \ldots \ldots \ldots \ldots \ldots \ldots \ldots, \ldots$

3.5 ACCESS CONTROL $\ldots \ldots \ldots \ldots \ldots \ldots \ldots \ldots \ldots \ldots \ldots$

3.6 BACKUP AND RECOVERY $\ldots \ldots \ldots \ldots \ldots \ldots \ldots \ldots \ldots$

4.0 TOOLS, TECHNIQUES, AND METHODOLOGIES ............. 9

5.0 SUPPLIER CONTROL $\ldots \ldots \ldots \ldots \ldots \ldots \ldots \ldots \ldots \ldots$

6.0 RECORDS COLLECTION AND RETENTION $\ldots \ldots \ldots \ldots \ldots \ldots$ 


\section{AUTOMATED TRANSPORTATION MANAGEMENT SYSTEM SOFTWARE CONFIGURATION MANAGEMENT PLAN}

\subsection{INTRODUCTION}

\subsection{PURPOSE}

This document describes the Software Configuration Management (SCM) approach and procedures to be utilized in ensuring and controlling the development process of the Automated Transportation Management System (ATMS). The sponsor has identified ATMS and its components as unclassified and non-sensitive. The configuration management procedures are necessary to ensure that any changes made to software and related documentation are consistent with ATMS goals and objectives and contained securely in a central library. The objectives of the Plan are to:

- $\quad$ Establish product baselines that support the change process

- $\quad$ Ensure that all system changes support ATMS goals and objectives

- Ensure that the potential impacts. of system changes are adequately evaluated prior to implementation

- Ensure that the latest approved versions of all software are being used in all environments (current production, development and future production)

- Establish a configuration status reporting standard that informs pertinent individuals of ATMS system status

- Ensure that the baselines always remain current with the production software and documentation

- Ensure that configuration management is integrated with other management plans designed to meet the overall objectives and goals of ATMS

- Ensure that the configuration library function of maintaining all master copies of documentation and software for each product is supported.

\subsection{SCOPE}

This plan applies to all software and associated documentation used in the production of the ATMS system. Software configuration items to be controlled by this plan include both procured software and applications software to be developed during the project. No distinction is made between phases of implementation of the project. 
The software products to be produced are applications software for the ATMS. Host software products, (e.g., a relational database management system) and peripheral host products, (e.g., forms generator software to aid the programmer in building data entry screens and a report generator to aid in building reports) will be provided for systems developers.

This SCM Plan specifically covers the configuration management for:

1. Development of system software

2. Development of system documentation

3. Continued system support following implementation.

In addition, this plan discusses the following subjects:

1. Configuration Identification - Description of the required documentation, project responsibilities, limitations of approvals with respect to specific control, and the review and delivery schedule.

2. Configuration Control - Description of configuration change procedures, software interface control, and organization interfaces.

3. Configuration Status Accounting - Description of procedures and forms used to record configuration status.

4. Reviews and Audits - Description of audit and review plans, method for handling deviations, change procedures, and relationships between reviews and the development cycle.

\subsection{OVERVIEW}

This SCM Plan covers the development of all ATMS software and associated documentation. The software and documentation are being developed by the ATMS Development Team, with guidance from the Technical Project Manager, the Integrated Program Coondinator, the ATMS Users Group, the ATMS Change Control Board (CCB), and the Transportation Automation Program Manager.

\subsection{DEFINITIONS AND ACRONYMS}

Definitions and acronyms used in this document will follow American National Standards Institute (ANSI)/ Institute of Electrical and Electronics Engineers (IEEE) 610.121990, Glossary of Software Engineering Technology (ANSI/IEEE 1990). 


\subsubsection{Definitions}

The following terms are used throughout this document.

Configuration Identification - (1) The process of designating the configuration items in a system and recording their characteristics; (2) The approved documentation that defines a configuration item; and (3) The current approved or conditionally approved technical documentation for a configuration item as set forth in specifications, drawings and associated lists, and documents referenced therein.

Configuration Item - (1) A collection of hardware or software elements treated as a unit for the purpose of configuration management; and (2) An aggregation of hardware/software, or any of its discrete portions, that satisfies an end use function and is designated for configuration management. Configuration items may vary widely in complexity, size, and type from an aircraft, electronic, or ship system to a test meter or round of ammunition. During development and initial production, configuration items are only those specification items that are referenced directly in a contract (or an equivalent in-house agreement). During the operation and maintenance period, any repairable item designated for separate procurement is a configuration item.

Configuration Management - The process of identifying, controlling, accounting for, and auditing an information system. The configuration of a system is measured at discrete points in time to identify and control changes and to maintain the integrity and traceability of the configuration. Configuration management is also a management control mechanism to ensure system changes are within the scope of the system design and to keep track of system change status.

Configuration Status Accounting - The recording and reporting of the information that is needed to manage a configuration effectively, including a listing of the approved configuration identification, the status of proposed changes to the configuration, and the implementation status of approved changes.

Production Library - A software library containing formally released versions of software and documentation.

Product - The hardware and software that are required for an application to operate.

Product Baseline - The state of hardware and software for an application and its associated documentation as it exists in the current production environment.

Release Package - A package containing all the components required to deliver a complete product release to the field, including release notification, release notes, installation notes, documentation, and software. 
System/Software Change Request (SCR) - The form that is used to report a software or hardware problem or to request ADP support from computer operations.

Software Library - A controlled collection of software and related documentation designed to aid in software development, use, or maintenance. Types include software development library, master library, production library, program library, and software repository.

\subsubsection{Acronyms and Glossary}

The following abbreviations and acronyms are used throughout this document.

$\begin{array}{ll}\text { ANSI } & \text { American National Standards Institute } \\ \text { ATMS } & \text { Automated Transportation Management System } \\ \text { CCB } & \text { Change Control Board } \\ \text { CMP } & \text { Configuration Management Plan } \\ \text { IEEE } & \text { Institute of Electrical and Electronics Engineers } \\ \text { IRM } & \text { Information Resource Management (Division of Westinghouse } \\ & \text { Hanford Company) } \\ \text { RCR } & \text { Review Comment Record } \\ \text { SCM } & \text { Software Configuration Management } \\ \text { SCR } & \text { System/Software Change Request } \\ \text { SDD } & \text { Software Design Description } \\ \text { SRS } & \text { Software Requirements Specification } \\ \text { V\&V } & \text { Verification and Validation }\end{array}$

\subsection{REFERENCES}

WHC, 1988, Standard Engineering Practices WHC-CM-6-1, Engineering Change Notice, Section EP-2.2: Engineering Document Change Control.

WHC, 1989, IRM Project Management, WHC-CM-3-2, Project Change Management, procedure 2.0100.07, and Change Control Guidelines for Production On-Line Applications, procedure 2.2015.

WHC, 1993, Software Practices, WHC-CM-3-10, Configuration Control, Section 6.0, Westinghouse Hanford Company, Richland, Washington. 


\subsection{MANAGEMENT}

\subsection{RESPONSIBILITIES}

The Technical Project Manager is responsible for administering ATMS configuration management. ATMS configuration management is divided into two phases:

1) Development phase: Software is controlled through release to the ATMS development library for acceptance testing. The Technical Project Manager acts as the software librarian controlling the release of the software during this phase.

2) Production phase: ATMS software configuration management is controlled by the ATMS change control board (CCB) and IRM operations production procedures. The ATMS CCB controls ATMS software and modifications when the software is transferred to production.

The general responsibilities of the Technical Project Manager during the development phase of configuration management are to process the information needed to control change requests in the software system as it develops, and to capture the as-built documentation, test data, reports, and code for the system.

Specific organizational responsibilities of the SCM coordinators are as follows:

- Establish naming conventions

- Approve change requests and plans

- Prepare necessary status reports and monitor project status

- $\quad$ Conduct regular reviews.

\subsection{INTERFACE CONTROL}

This SCM plan interfaces with the following plans:
- Test Plan
- Implementation Plan
- Documentation Plan.

\subsection{IMPLEMENTATION}

This SCM plan has the following implementation schedule for when items first become configuration items: 
1. December, 1992 - ATMS Functional Requirements Document

2. January, 1993 - ATMS Data Requirements Document

3. March, 1993 - ATMS Implementation Plan

4. May, 1993 - ATMS Configuration Management Plan

5. May, 1993 - ATMS Security Plan

6. June, 1993 - ATMS Quality Assurance Plan

7. August, 1993 - ATMS Training Plan

8. September, 1993 - ATMS Documentation Plan

9. September, 1993 - ATMS Verification and Validation Plan

10. Fiscal Year 1994 - ATMS Test Plan

11. Fiscal Year 1994 - ATMS test materials

12. Fiscal Year 1994 - ATMS released software, and the initiation of the ATMS Change Control Board

\subsection{POLICIES AND PROCEDURES}

The following procedures will be followed for all documents, software, etc., named in this plan as configuration items.

- Engineering Document Change Control, Section EP-2.2, Standard Engineering Practices, WHC-CM-6-1 (WHC 1988)

- Project Change Management, procedure 2.0100.07; and Change Control Guidelines for Production On-Line Applications, procedure 2.2015, IRM Project Management, WHC-CM-3-2 (WHC 1989)

- Configuration Control, SP-6.0; Document Control, SP-6.1; Software Control, SP-6.2; Change Requests and Problem Reports, SP-6.3; and Document Approvals, SP-6.4, Software Practices, WHC-CM-3-10 (WHC 1993). 


\subsection{SOFTWARE CONFIGURATION MANAGEMENT ACTIVITIES}

\subsection{CONFIGURATION IDENTIFICATION}

This section describes how ATMS documents and software will be identified.

\subsubsection{Document Identification}

All ATMS documents will be named in accordance with the instructions outlined in Standard Engineering Practices, WHC-CM-6-1, Section EP-1.12. The person preparing a supporting document requests an identification number from a Configuration Documentation Work Station operator. The ATMS document numbering convention is as follows:

WHC-SD-XXX-YYY-999 Rev. Z

WHC - identifies the DOE contractor

SD - identifies the document as a Supporting Document

XXX - identifies the program indicator (e.g., WM for Waste Management, or TP for Transportation and Packaging)

YYY - identifies the supporting document type

999 - identifies the unique document number

$\mathrm{Z} \quad$ - identifies the revision number of the document

\subsubsection{Software Identification}

All ATMS software will be named in accordance with WHC Software Practices, WHC-CM-3-10, Section SP-6.2. The ATMS naming convention is as follows:

XXX-Y-ZZZ.999

XXX - identifies the name of the module

$\mathrm{Y}$ - identifies the module as

$M$ - for a menu identifier

D - for a display identifier

$U$ - for a update identifier

$\mathrm{R}$ - for a report identifier

ZZZ - sequential number for unique identification

999 - sequential version number

\subsection{CONFIGURATION CONTROL}

Baselines are established by the DOE headquarters program manager's approval of the document. ATMS will utilize a change control board after the system enters the production 
environment. The purpose of the CCB is to decide approval/disapproval and priority appointment of technical changes to ATMS.

\subsection{CONFIGURATION STATUS ACCOUNTING}

Status accounting is accomplished by tracking the changes to modules generated from the change control log. The software unit development folders will contain a copy of a change control log. As software modules are generated, a copy of the source code will be placed in the unit development folders and duly noted on the log. Modules which are changed or modified will have updated source code listings placed in the unit development folders and appropriately documented on the change control $\log$ as to version and the nature of the change. During ATMS development, the Technical Project Manager will regularly survey the change control log for any modifications to the baseline system. The change control $\log$ will be used to formally prepare all required engineering change notices as required.

Change requests to the development programs will be reported to the Technical Project Manager on a weekly basis. When the software module is released for formal module testing, the release and version number are recorded along with the current change level. In addition, the Technical Project Manager will oversee the project through regular weekly status reports from development team members.

\subsection{AUDITS AND REVIEWS}

To ensure proper execution of procedures in support of the configuration management function, and to identify any areas in the procedures that require modifications, the Technical Project Manager should conduct periodic informal reviews and audits.

The Audits and Reviews procedure should be conducted to measure the proper execution of activities relative to the control and processing of change requests. Included in these informal reviews should be a periodic assessment of the interfaces occurring with development team activities to ensure their adherence to sound Configuration Management procedures. This procedure also involves comparing the physical contents of the ATMS products running in the production environment (i.e., software, documentation) to the records maintained in the CM Library. This will ensure the effectiveness of library controls and the integrity of library contents.

\subsection{ACCESS CONTROL}

Access to ATMS software and data will be controlled through the use of passwords. Further details about the access control plan can be found in the ATMS System Security Plan. 
Since ATMS hardware typically consists of personal computers at the local site that are used for other purposes, access to the hardware will not be controlled.

\subsection{BACKUP AND RECOVERY}

Computer equipment, software, and data are susceptible to damage, loss, or destruction. To protect ATMS from such risks, a backup and recovery procedure has been established and is contained within the ATMS System Security Plan.

\subsection{TOOLS, TECHNIQUES, AND METHODOLOGIES}

Configuration management procedures will be used to monitor and control the release of ATMS software and documentation into production libraries. Deployment of software will be performed using similar control procedures.

\subsection{SUPPLIER CONTROL}

Contract-developed software will form the basis of ATMS. The subcontractor will be responsible for releasing software in accordance with this SCM Plan.

\subsection{RECORDS COLLECTION AND RETENTION}

Status reports will be maintained as a historical record for the ATMS project in the project notebook. All test data, test procedures, and test results will be maintained and saved for use in defining the production system, including the software unit development folders and associated change control logs. Baseline code, test data and reports will be maintained at the termination of the project for two years. All associated documentation will be maintained in the Records Holding Area for a two-year period. 

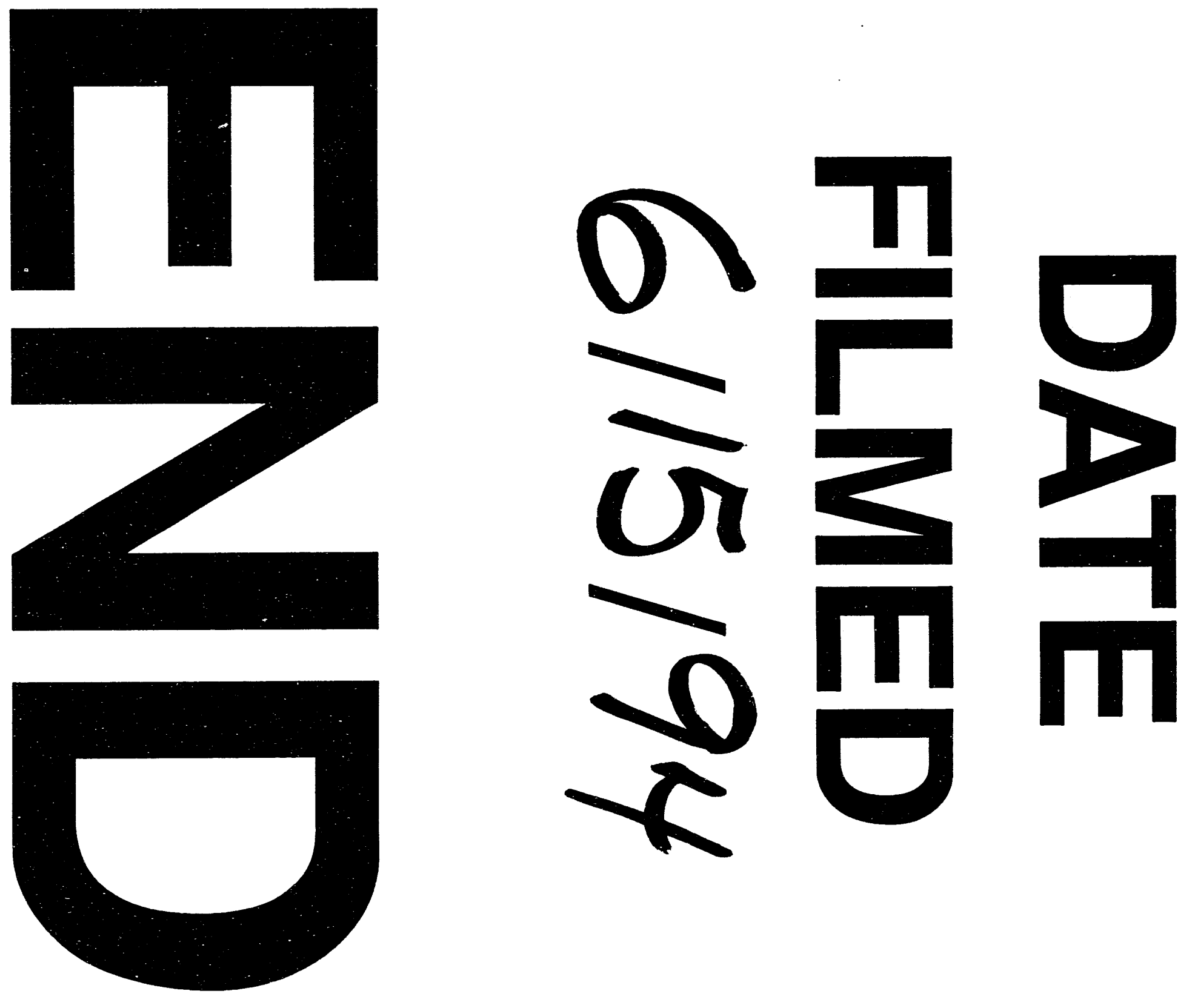
